\author{
SUBMITIED TO Particle Accelerator Conference \\ May 13-16, 1985 \\ Va:couver, British Columbia
}

LA-UR- $-85-1736$

DE85 012724

TITLF MAJOR FACILITY OVERHAULS AT LAMPF

\title{
DISCLAIMER
}

This report wan prepared as an account of wurk sponsored by an ugency of the United States Government. Neither the United States Government nor any agency thereof, nur any of their employees, mukes any warranty, express or impliod, or assumes any logal liability or responsibility for the uecuracy, completeness, or usefulnens of uny information, apparatus, product, or process disclowod, or represents that its use would not infringe privately owned rights. Reforence hereill to any specific cummercial product, process, or service by trade name, Irademark. manufacturer, or otherwise does not necessurily constitute or imply its endorsement, recom. mendstion, or favoring by the United Stales (jovernment or any agency thereof. The viows and opinions of authors expressed herein do not necessarily stute or reflect those of the Unitod Stuten Ciovernment or any agency thereof. 


\section{MAJOR FACILITY OVERHAULS AT LAMPF}

D. L. Grisham, J. E. Lambert, and W. F. Sosmer, Jr. Los Alamos National Laboratory

P. O. Box 1663, Group MP-7/13, MS H840/H838 Los Alamos, New Mexico 87545

\section{Abseract}

The Clinton P. Anderson Meson Physica acility (LAMPF) is a linear proton accelerator designed to operate at $800 \mathrm{MeV}$ and $1.0 \mathrm{~mA}$. It has been operating a. power levels above 200 microamperes ince February of 1976 and now routinely operates near the design level.

Th1s paper outlines the problems encountered with the original target cell components, the repalis required since 1976, and specifically detalls the steps involved in the complete replacement of the vital target cell components. These components Include target boxes, collimators, main beam line magnets, and the front-end manets of the secondary beam 11 nes.

The A-2 target cell was replaced in the spring of 1983 and the $A-1$ target cell was replaced in the spring of 1984. Both have operated satisfactorily since their completion, with only minor difflculties. The overhaul and total component replacement in the beam stop area $(A-6)$ was completed In early May 1985 and has fust been placed in operation. The upgride. in addition to the replacement of the beam stop and the vacuum-to-alr window with state-of-the'-art designs, provides a greatly increased capability of both proton and neutron 1 rradiation of materials.

\section{Remote Handiling System}

Previous papers and another paper in these proceedings detail the design and the operational capablllty of the Monitor remote handling system. Degiription of Monltor in th1s paper will be liolted c1) operational descriptions of the rarget cell replacements.

\section{History nf The Target Cells}

The original targer cells were designed, fabrlcated, and installed in 1974 and 1975. Figure 1 schematcally deplics a typlcal targat cell, in this chye $A-2$. This figure 1 llustrates the normal elements in the LAMPF cells and their relation to the target box. Since the target box is the key element in the cell, 1ts design, fabrication, and Inatallation wlll be thoroughly covered.

After a few years of operation, water and vacuum leaks developed at rates that gerlously threatened operating schedules. A major portion of the temperature Instrumentation became Inoperable, which made the reduction of coollng water flow to minlmlze leakage an unacceptable risk without other masures. The cemporary golution was the installation of thinner targec to compensate for reduced coollng. Repalrs were made on a continulnd basis, but the llnal molution was the total roplacement of the targut cell.

The orlglnal target hox was rectangular in mhape with copner coollng colls brazed to the outalde murfaces. The primary cause of the uncontrollable water leaks way the cracklng of the copper rubes at or near the brazed folnt to the stalnlesn steel vacuum bus.

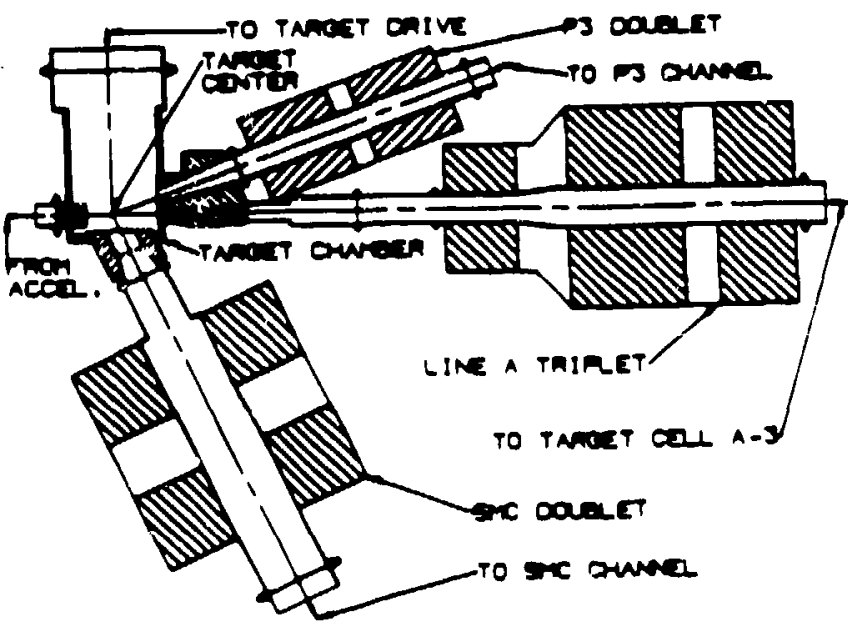

Flg. 1. Target cell layout.

Due to severe thermal cycling, all the vacuum leaks occurred 1 in folnts near the target box. The vacuum folnts eventually loosened and lesks developed, due to atcheting effect in the wedge-type clamps and flanges used.

\section{Planning and Design Consiterntons}

In the design of the new cells, the flrst problem was to devise a method of remotely matching the new target box to the existing vacuum ports in each of the cells. As shuwn in Fig. I, the target box must be aligned to the Line A triplet, two secondary beam line magnets, target-drive flange, and an existing vacuum Ine from the upstream target cell.

This a: Ignment was accomplished by designing a fixture that gimulated the target box. With adjugtable tlanges that conlf be mated to the exigting vacuum connections. TI. f 1 xture would then be used to congtruct a flg in whlich the new target box was assembled.

The other problems were to destin the new components to reduce the nosalbliltien of water leaks and vacuum flange thermal cycling. Flgure 2 is a sectiored isometrlo metch of the new A-2 target chamber (the $A-1$ box 1s slmilar). The eyllndrlcal design is better than the ortginal rectangular one trom theiral gradient and an associnted thermal scress atendpoint. The cooling of the copper collimators is by hellcal water pasagen machined in the copper. The maln box shell is cooled by flowing water in the annjlar space between the Inner and outer ahell. Vecuum jolnta, previously subjected to extremcly high heating raten, were moved to a muith lover heating rate reglon outalde the copper collimators. Thin move has oo far aliminated the vacuum leak problem. 
Actual Target Ge11 Replacements (A-1 And A-2)

The actual remote replacement of the target cells consisted of the following steps:

- remove all of the existing equipment frow the cell and transport it to the disposal site:

- Install new magnets in the main and secondary beam lines and match the alignment fixture to the flanges as shown in Fig. 3;

- construct an assembly $j 1 \mathrm{~g}$ matched to the alignment f1xture and assemble the new target box;

- Install the new target box in the cell and remotely mate $1 t$ to the other flanges; and

- Install and checkout cooling water and thermocouple systems as well as check all vacuum jolnts for leaks.

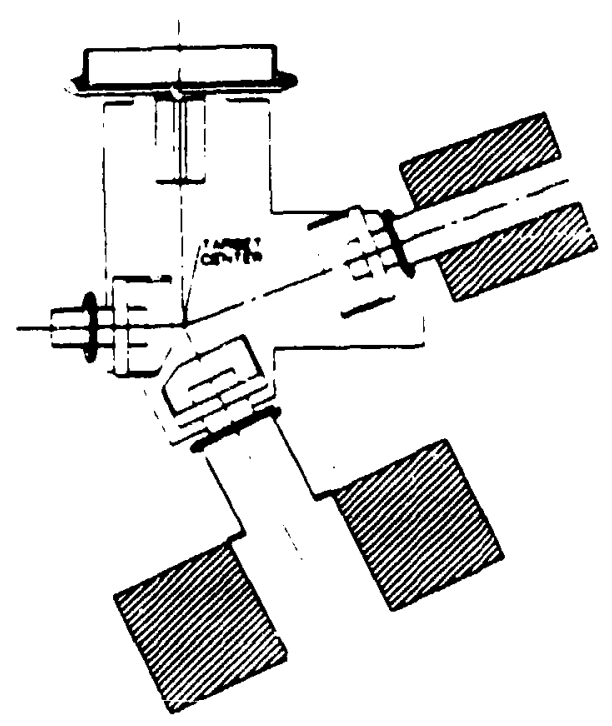

F1g. 3. Alignment $\mathrm{flg}^{1 \mathrm{~g}}$ schematic.

\section{Target Cel1 A-6 Replacement}

The A- 6 cell was originally designed sich a beam stop, an alr-cooled vacuum-to-alr window, nine stringerg for medical isotope production, and three radiation damage stringers for neutron liradiations. Eventually a water-cooled vacuum-to-alr window and $20 \mathrm{~cm}$ water degrader, to enhance neutrino production, were added. Since uccess to these components required about ten shifts to move the shlelding door and the stacked steel shielding, the turnaround time for repalis was almost two calendar weeks.

In recent years, there has been considerablo interast in developing a linger scale capabllits to do both neutron and pricon lrradiations of materials. This has been partly driven by a collaboration hetween LAMPF and the West German designers of the spallation reutron facl11:y (SNQ).

The result is the new $A-h$ area shown $1 \mathrm{n}$ Fig. 4. It provides the previously mentioned facl $11 \mathrm{cles}$, minus the ortginal radiation damage atringers, but adds three proton-leradiation and twelve neutrunirradiation ports. 


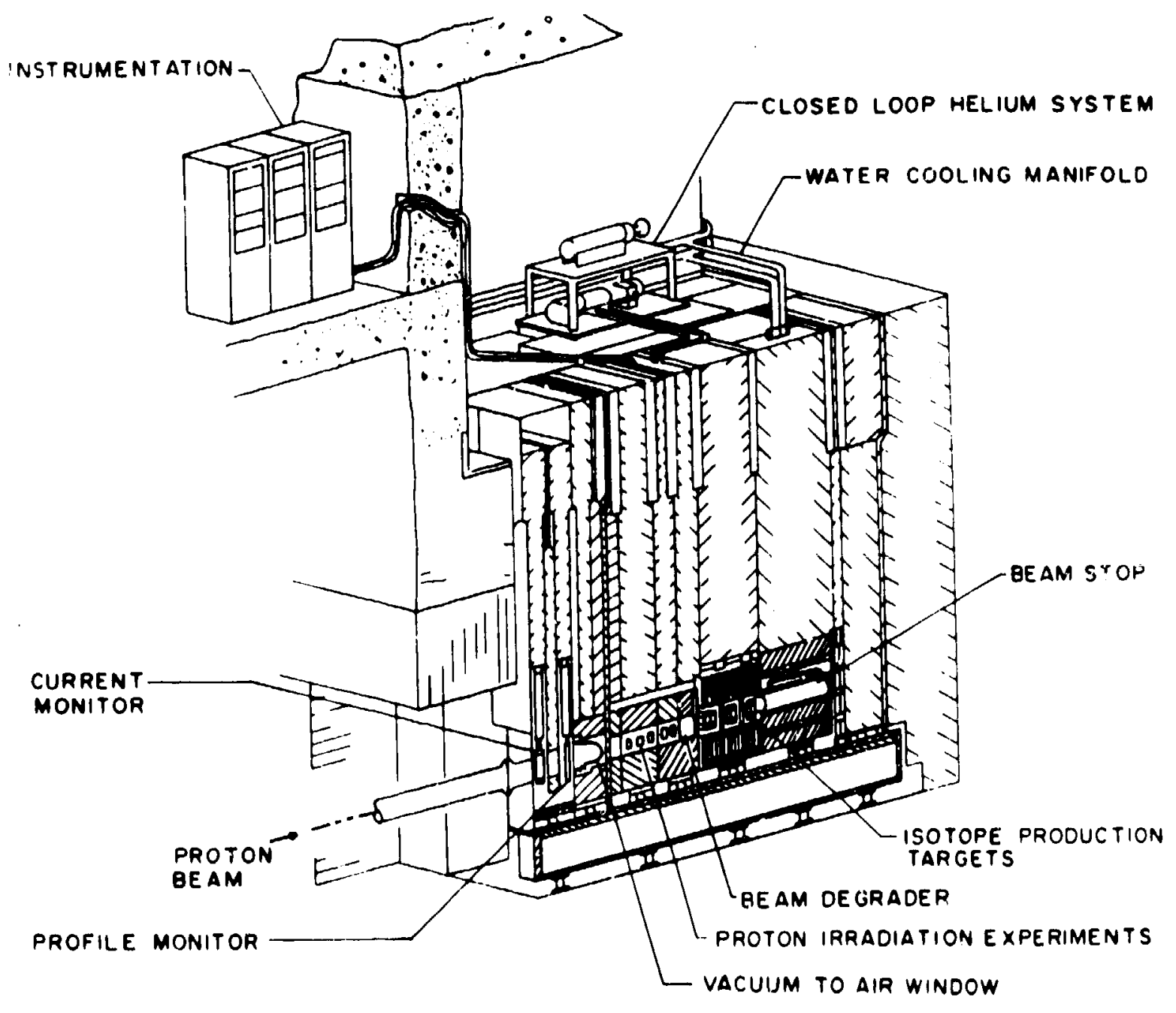

$\overrightarrow{1-u^{\prime \prime}}$

FIg. 4. New A-6 tarket cell.

The pherdicional capabllley is enormougly ellhaniad because the vertical Ingert deslgn provides one to four shift turuaround tames for replacement of any component or experiment In the tarnet cell.

The nes syutem is now installed and is operatonal with all componeita and three proton irradlation axperimente from sivo in place. lintills of the remote handlling to ennetruet the now faclite are pluen in ancther paper in this procondlake.

\section{Conciusions}

The overhaul and complete rillacement of highly radioactive target co:ls and ocher larqu farllities can be suciessfully performed usling remote handling quatems like Monltor. Thla technologe is applicable to wate disposal and tho decommlationting if nucleat facillties. 